\title{
SYMBOL IN EDGAR ALLAN POE'S SELECTED SHORT STORIES AND THEIR PEDAGOGICAL IMPLICATION: A SEMIOTIC PERSPECTIVE
}

\author{
Arinfandira Ramadhanti ${ }^{1 *}$, Lalu Muhaimi ${ }^{2}$, Nur Ahmadi ${ }^{3}$ \\ ${ }^{1,2,3}$ English Department, Faculty of Teachers Training and Education, University of Mataram \\ *Email: arinfandirarama@gmail.com
}

Received : November 02 ${ }^{\text {th }}, 2019$, Accepted : November $20^{\text {th }}, 2019$, Published : November $30^{\text {th }}, 2019$

\begin{abstract}
The main objectives of this study are to identify the symbols which are contextually attached to certain words and phrases; to analyze the contextual meaning of the symbols; and to describe the pedagogical implications of the uses of those symbols to the practices of teaching English as a foreign language (TEFL). These all are conducted by following Pierce's triadic theory. The sources of the data of this study are some carefully selected short stories written by Edgar Allan Poe. Descriptive qualitative method is used to collect the data which are then analysed and presented explanatorily. The results of the analysis of the data suggest that there are six symbols which are contextually attached to words and phrases in The Masque of Red Death, three symbols in The Pit and Pendulum, and three symbols in The Black Cat. Those symbols carry important pedagogical implications to the teaching of English as a foreign language. This implies that teachers of English may use these short stories and their symbols to teach English vocabulary in reading section by using flashcard, and by which they can conclude the learning section by presenting the moral values in the short stories.
\end{abstract}

Keywords : Symbols, Semiotic

\section{INTRODUCTION}

There are many famous short story writers around the world such as Anton Chekov, Isaac Babel and James Baldwin. But there is a unique one among well-known short story writers, that is Edgar Allan Poe. He is an American writer, editor and literary critic who is best known for his poems and short stories for decades, particularly his tales in mystery and macabre. Unlike the other writers who wrote stories in various genres, he prefers to produce it in several specific genres such as gothic, horror, dark, detective and scifiction. Due to these reasons, he was claimed as one of the earliest practitioners of short story and generally one of the inventors in detective and sci-fiction genres. His short stories are very interesting to study not only because it is always surrounded by the same genres but also the contents and plots is similar to his real life.

The previous research about symbols in Edgar Allan Poe's selected works was done by Shegufta Rahman (2015) which is entitled Significance of Symbolism in Edgar Allan Poe's Selected Works. In this research, it elaborated significant symbols which is involved in story themes and divided them into several ones. Another similar previous study of symbols was done by Yeni Ariska which is entitled The Symbols of Marriage in Henry James' Novel The Golden Bowl'. In this prior research, the symbols specifically were viewed by Saussure's semiotic theory in order to determine hidden meanings of the novel through literary criticism which is slightly different from this study viewed through Pierce' triadic theory.

Symbol is anything which signifies something in broadest sense. However, in literature, the term 'symbol' is applied only to a word or phrase that signifies an object or event which in its turn signifies something or has reference beyond itself (Abrams, 1999:311). Semiotics is a study of sign system in which there is assumption that every sign, system in nature, society and cognition belongs to domain of semiotic. According to Kirszner (2016:407), there are two distinction term in term of symbols. Those are typically draw a distinction between "conventional" (or "universal") symbols, and "contextual" (or "literary") symbols. The study of 
linguistic meanings of morphemes, word, phrases, and sentence is called semantics. Semantic is considered with aspect of meaning in language. Dealing with the meaning, it could be categorized into some reference.

At around the same time as Saussure was formulating his model of the sign and of 'semiology' (and laying the foundations of structuralist methodology), across the Atlantic closely related theoretical work was also in progress as the pragmatist philosopher and logician Charles Sanders Peirce formulated his own model of the sign, of 'semeiotic [sic]' and of the taxonomies of signs. In contrast to Saussure's model of the sign in the form of a 'self-contained dyad', Peirce offered a triadic (three-part) model consisting of the representamen: the form which the sign takes (notnecessarily material, though usually interpreted as such) -called by some theorists the 'sign vehicle'; an interpretant: not an interpreter but rather the sense made of the sign; an object: something beyond the sign to which it refers (a referent).

\section{METHODS}

This study used qualitative descriptive research method in which the meaning of some symbols in Edgar Allan Poe's selected short stories are tried to elaborate. Qualitative descriptive actually comes from two different terms; qualitative and descriptive. Qualitative is a research method which uses collective data where the data is explained as the source of data. The sources of the data of this study are the writings of original author. In this case, the data sources which was divided into two groups, primary and secondary data. The primary data are Edgar Allan Poe's three selected short stories which are The Masque of Red Death, The Pit and Pendulum, and The Black Cat. The secondary data are any sources, articles, journal and books which is related to the primary data of this study.

The data of this study are collected using library research by collecting coherent library materials with the object of the study. The data which are contained in the literature is collected and processed by way of comprehensive reading, organized through a predetermined theories and perspectives, and conduct further analysis of the results of data compilation using rules, theories and methods that have been determined so that certain conclusions (inferences) are obtained which are the results of answers to the problem statement.

\section{DISCUSSION}

The Masque of Red Death, The Pit and Pendulum and The Black Cat are short stories written by Edgar Allan Poe, a famous American Writer. It is found that there are six symbols which is contextually attached to words and phrases in The Masque of Red Death , three symbols in The Pit and Pendulum and three symbols in The Black Cat which those symbols.These symbols have pedagogical implication in Teaching English as Foreign Language. Teacher is able to use these short stories and their symbols to teach English vocabulary in reading section by using flashcard and conclude the learning section by presenting the moral value.

It is deliberated and found in this study that Poe's life is filled with unhappiness which it is not surprising that he chose to write about the type of characters who killed, maimed, and suffered. From his parents' early deaths to his adopted father disowning him, Poe seemed to symbolize his tragic life into his short stories whose readers is aimed to seek the hidden messages through the symbolic expression which is put inside. He has many popular short stories but three best of them are The Masque of Red Death, The Pit and Pendulum and The Black Cat. Those short stories are quite interesting ones to study not only because of their popularity but also the limited characters which reveal more contextual symbolic expression attaching certain towards in several part of the story. The interpretation of the symbols conveys the original message and aims of the story itself.

The use of symbols of three selected short stories is important to study. This means that there is a substantial need to study them with focus on contextually used symbols which are attached in certain to words of the three selected short stories to help other readers to convey the messages. Moreover, the results of this study implicate the way students learn English vocabulary which is not only emphasized on the literal meaning of certain words but also the additional meaning beyond. It helps them understand one word with various context and wide range of meanings.

There are many kinds and meaning of symbols in Edgar Allan Poe short stories. However, studying and analyzing the use and meanings of these symbols are beyond the scope of this study. This discussion is restricted to symbols which contextually attached to certain 
words in three selected short stories and the pedagogical implications of the use for these symbols are also made the other coverage of this study.

\section{CONCLUSION}

The Masque of Red Death, The Pit and Pendulum and The Black Cat are short stories written by Edgar Allan Poe, a famous American Writer. It is found that there are six symbols which is contextually attached to words and phrases in The Masque of Red Death, three symbols in The Pit and Pendulum and three symbols in The Black Cat which those symbols.

In analyzing the symbols and their contextual meanings, there are many other aspects which needs further research to conduct by other researcher in these three short stories such as allegory, metaphorical expressions, characterization, and extrinsic motivation.

\section{REFERENCES}

Abrams, M. (1999). A Glosary Of Literary Terms. United Stated of America: Thomson Learnin Inc.

Baldick, C. (1990). The Concise Oxford Dictionary of Literary Terms. Oxford: Oxford University Press.

Boulton, M. (2015). Icons, Symbol and Index. Semiotic Web, 1-4.

Chandler, D. (2007). Semiotic The Basic. New York: Taylor and Francis Group.

Danesi, M. (2004). Messages, Signs and Meanin: A Basic Textbook in Semiotic and Communication Theory. Toronto: Canadian Scholar Press Inc.

Eco, U. (1979). Theory of Semiotics . United State of America: Indianan University Press.

Gibaldi, B. a. (1982). Interrelation of Literature. New York: The Modern Language Association of America.

Kirszner, L. G. (2016). Compact Literature: Reading, Reacting, Writing. Cengage Learning.
Mount, T. (2017, August 25). Masque of the Black Death: How Europe's Ruler Resisted The Plague in Vain. Retrieved 10 07, 2019, from History Answer: https://www.historyanswers.co.uk/mediev al-renaissance/masque-of-the-black-deathhow-europes-rulers-resisted-the-plaguein-vain.

Sebeok, T. (2001). An Introduction to Semiotics. Canada: University of Toronto Press.

W, G. M. (2008). The Elements of Library Research. Princeton: Princeton University Press.

W.Kreidler, C. (1998). Introducing English Semantics. London: Routledge.

Webster, M. (2019, October 18). Retrieved October 18, 2019, from Webster Online Dictionary: $\quad$ http://www.merriamwebster.com.

Wikipedia. (2019, September 20). Torture Chamber. Retrieved October 18, 2019, from Wikipedia: https://en.wikipedia.org/wiki/Torture_cha mber. 